\title{
Factors influencing participation in the beef quality assurance program of the West Virginia Cooperative Extension Service
}

\author{
Sara D. Peacock \\ West Virginia University
}

Follow this and additional works at: https://researchrepository.wvu.edu/etd

\footnotetext{
Recommended Citation

Peacock, Sara D., "Factors influencing participation in the beef quality assurance program of the West Virginia Cooperative Extension Service" (2003). Graduate Theses, Dissertations, and Problem Reports. 1765.

https://researchrepository.wvu.edu/etd/1765

This Thesis is protected by copyright and/or related rights. It has been brought to you by the The Research Repository @ WVU with permission from the rights-holder(s). You are free to use this Thesis in any way that is permitted by the copyright and related rights legislation that applies to your use. For other uses you must obtain permission from the rights-holder(s) directly, unless additional rights are indicated by a Creative Commons license in the record and/ or on the work itself. This Thesis has been accepted for inclusion in WVU Graduate Theses, Dissertations, and Problem Reports collection by an authorized administrator of The Research Repository @ WVU. For more information, please contact researchrepository@mail.wvu.edu.
} 


\title{
Factors Influencing Participation in the Beef Quality Assurance Program of the West Virginia Cooperative Extension Service
}

\author{
Sara D. Peacock \\ Thesis submitted to the \\ Davis College of Agriculture, Forestry and Consumer Sciences \\ at West Virginia University \\ in partial fulfillment of the requirements \\ for the degree of \\ Master of Science \\ in \\ Agricultural Education \\ Kerry S. Odell, Ph. D., Chair \\ Harry N. Boone, Jr., Ph.D. \\ Phillip I. Osborne, Ph.D. \\ Division of Resource Management \\ Morgantown, West Virginia \\ 2003
}

Keywords: Agricultural Education, Beef, Beef Quality Assurance, Extension Education 


\section{ABSTRACT \\ Factors Influencing Participation in the Beef Quality Assurance Program of the West Virginia Cooperative Extension Service}

\section{Sara D. Peacock}

The purpose of this study was to identify factors that contribute to participation in the West Virginia Beef Quality Assurance program. This study explored barriers and encouragers that affected involvement in educational programs offered by the West Virginia Cooperative Extension Service. The population consisted of 387 West Virginia Beef Producers from the West Virginia Young Sire Performance Evaluation Program mailing lists. The sample consisted of 85 producers randomly selected from the accessible population and 85 responses to the survey were completed. It was found that the average BQA farmer had a higher net income from their farming practices and had a larger herd than non-BQA participants. They were more likely to be informed on current trends in the beef industry and more prepared for change. Non-BQA participants credited barriers such as time and convenience to lack of participation. They believed increased program awareness and closer training locations would increase involvement. 


\section{DEDICATION}

This thesis is dedicated to my family. To my parents who have always told me that I could do anything, as long as I was willing to work for it. And to my husband, who has been as supportive all the way through. Thank you, and this is for you all. 


\section{ACKNOWLEDGEMENTS}

There is no substitute for great friends and great teachers. I have been lucky to have both. My heartfelt thanks go out to Dr. Dennis K. Smith, without whom, none of this would have happened. He always had a word of encouragement or a joke for me. I have never worked with a better person.

Special thanks go to Dr. Kerry S. Odell. He became my advisor after I had been searching for a major that suited and provided guidance and inspiration. Sincere appreciation goes to Dr. Harry Boone. He stepped in to make a transition easier for everyone involved and handled everything in stride. Gratitude to Dr. Phil Osborne, I would have been unable to work with BQA without his assistance, and for the encouragement that he provided along the way.

I would also like to note the help that many other professors and students of the Davis College of Agriculture, Forestry \& Consumer Sciences have given me along the way. I will miss you dearly. This place has given me many memories, and I will treasure them. 


\section{TABLE OF CONTENTS}

ABSTRACT
DEDICATION.
ACKNOWLEDGEMENTS
TABLE OF CONTENTS
LIST OF TABLES
CHAPTER I: Introduction
Background and Setting
Statement of the Problem
Purpose of the Study
Objectives of the Study Limitations of the Study
Definitions.t.

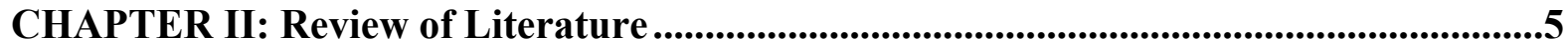

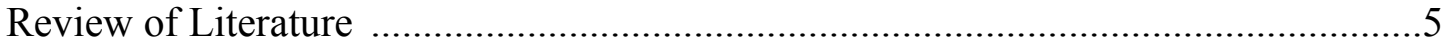

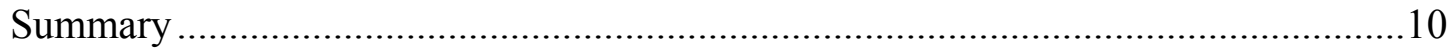

CHAPTER III: Methodology .........................................................................................................11

Purpose of the Study …………………….........................................................11

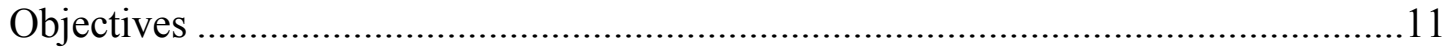

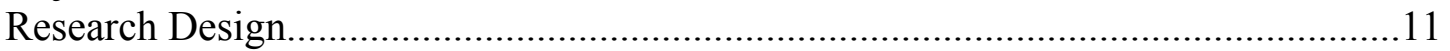

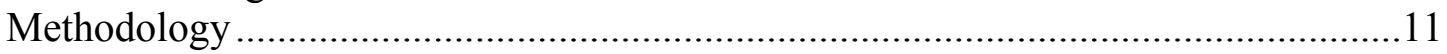

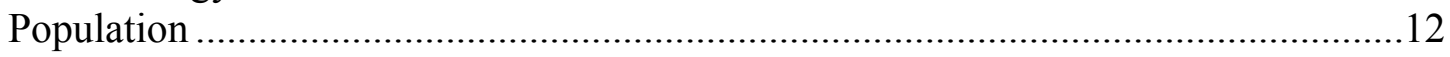

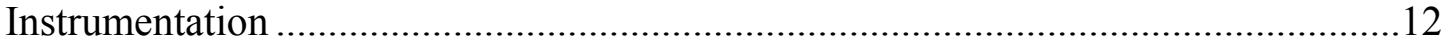

Data Collection Procedures....................................................................................13

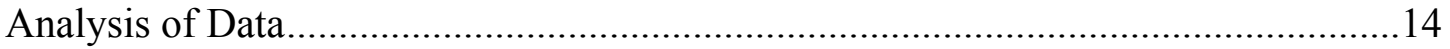

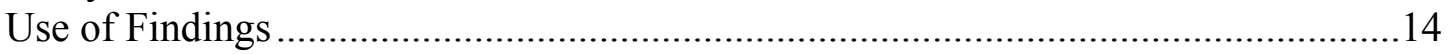

CHAPTER IV: Findings .........................................................................................................16

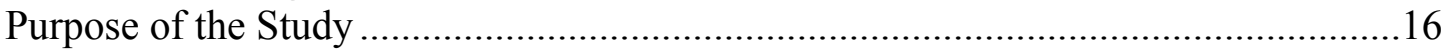

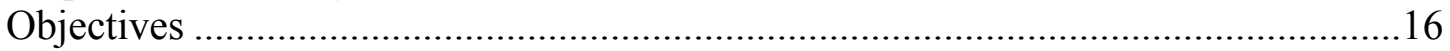

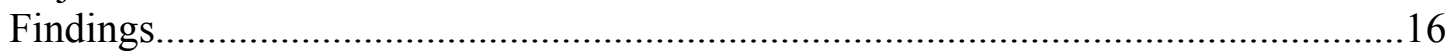

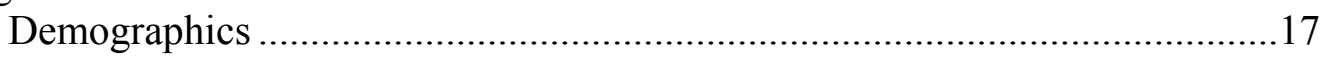

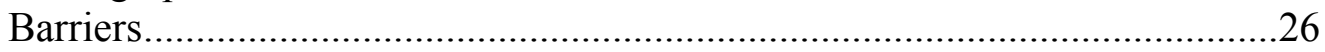

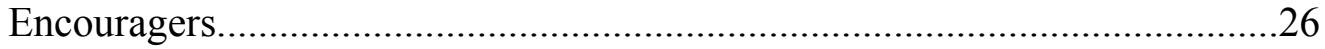

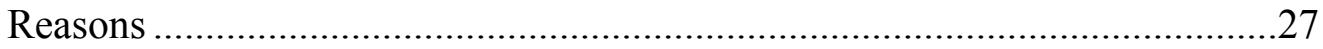

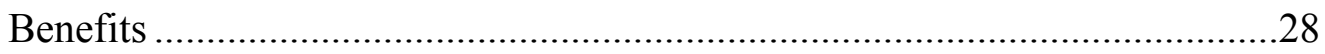

Qualitative Responses............................................................................28

CHAPTER V: Summary, Conclusions, and Recommendations ...........................................30

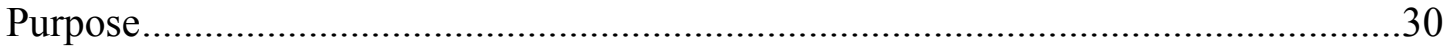

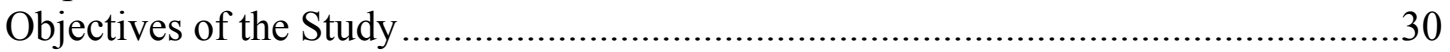

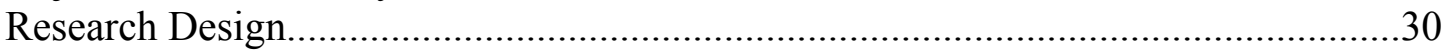

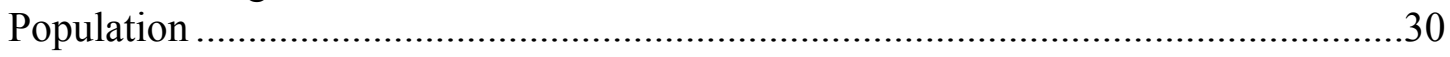

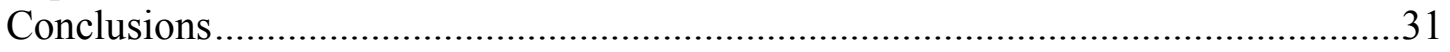

Recommendations ............................................................................................34

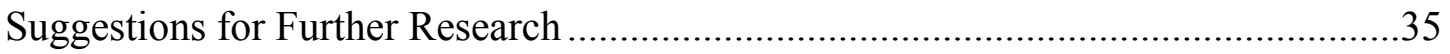




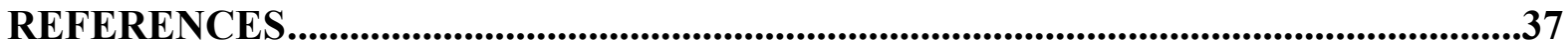

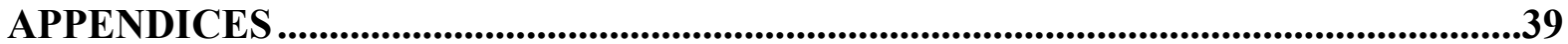

APPENDIX A: Introductory Telephone Statement ................................................40

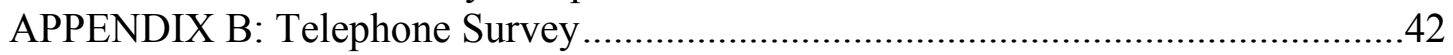

APPENDIX C: BQA Guidelines from Cattlemen's Association ..................................45

APPENDIX D: WV BQA Operational Guidelines …………………………...........49

APPENDIX E: Comments made to Question 22 of the Survey ...................................53

APPENDIX F: Geographic Location of Respondents.............................................56

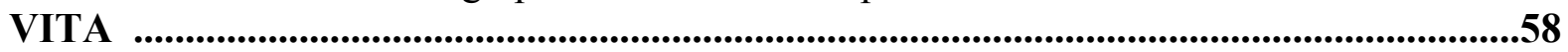




\section{LIST OF TABLES}

Table

Page

1. Demographic Characteristics of West Virginia Beef Farmers .....................................17

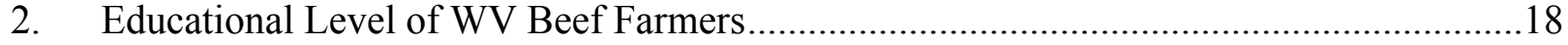

3. Cattle Breeds Raised by WV Producers ...................................................................19

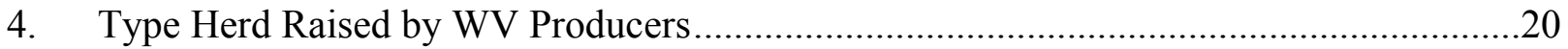

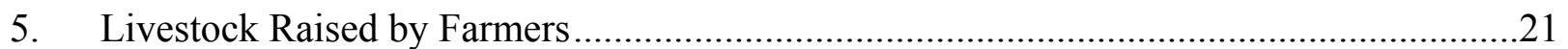

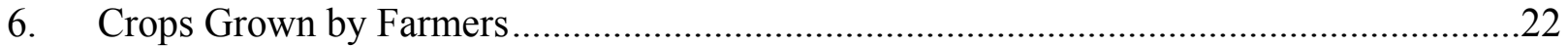

7. Where Farmers Obtain New Information for Their Operations ..................................23

8. Knowledge of Country of Origin Labeling (COOL) \& Affect on Operation....................24

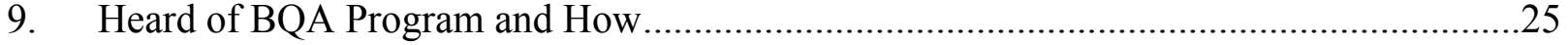

10. Barriers to Participation in WV BQA Program ...........................................................26

11. Encouragers to Participation in WV BQA Program ....................................................27

12. Reasons for Participating in WV BQA Program .......................................................2

13. Benefits Seen to Participating in WV BQA Program ..............................................28 


\section{CHAPTER I}

\section{Introduction}

\section{Background and Setting}

In 1914 the Smith-Lever Act established the Cooperative Extension Service to aid the rural farmers in their goal to be more efficient. Today, its name has changed to the Cooperative State Research, Education and Extension Service (CSREES) and its mission is "to advance knowledge for agriculture, the environment, human health and well being, and communities," (Learn About CSREES, 92 ). The extension service strives to provide programs that improve the lives of the people in the communities served. One such program that is being conducted in a number of states is the Beef Quality Assurance program (BQA). This program was initiated in West Virginia to improve the standards that farmers are currently utilizing in their operations.

Beef is a consumer-driven industry; therefore farmers must meet consumer demand for quality. "The consumer's lack of knowledge about agricultural production coupled, with concern for misuse of technological advances in agriculture has created great concern for the safety of their food supply” (Blezinger, March 2002, ๆ 4). “In 1991, the Beef Quality audit estimated that $\$ 280$ per slaughter steer/heifer was lost to the industry because of quality shortfalls" (Taylor, 1994, p. 33). This pointed to a need for a program to educate the producers to decrease the losses due to inadequate quality.

Between 1982 and 1985, three feedlots and the USDA FSIS evaluated production practices to assess residue risks. In 1985, after careful analysis and adjustment of production practices, these three feedlots were certified by the USDA FSIS as Verified Production Control Feedlots. What was learned during those three years now serves as the backbone for the NCBA's BQA program. Success of the effort 
is clear; violative chemical residues have almost disappeared in fed beef cattle and injection site lesions have been reduced by over 67\%. (Ohio BQA, 2001, p. 5)

The NCBA has been responsible for the widespread movement of the BQA program. Currently 40 states are involved in the program. The program addresses issues such as preharvest pathogen and product control" that other parts of the food industry have dealt with for years (Beef Quality Assurance, \ 7). It is the goal of BQA to "ensure that beef and dairy cattle are maintained in a manner which will result in a safe and wholesome beef product for the consumer" (BQA Certification manual, 2002, p. 2).

The West Virginia BQA program was developed to meet the need for quality control. It is a partnership between the West Virginia Cooperative Extension Service, the West Virginia Cattlemen's Association, and the West Virginia Department of Agriculture. The program promotes a series of best management practices for small beef cattle farmers, and strives to help such farmers get the most from their beef operation by adapting research and development activities that larger cattle operations have benefited from for years. The affiliation of these three groups is beneficial to the farmer because it combines the strength of an educational institution (Extension Service) with the policy capabilities of a professional organization (the Cattlemen's Association).

This program is designed as a series of best management practices and it addresses consumer concerns about the beef industry such as food safety, bio-security, and food production techniques. It educates producers through a two-phase educational series. Phase one of the program is a classroom lecture series to address the role of the producer in food safety, product quality, and consumer acceptance. Phase two of the training is a chute side, hands on educational experience. Extension faculty and pharmaceutical field veterinarians and 
representatives assist in instructing producers on the techniques of handling and administering vaccine. (Osborne, 2001, p. 1)

Through technology and education, beef producers can improve production techniques, reduce carcass losses, and heighten profits. Large corporations devote segments of their workforce to research and development in order to meet consumer demands and anticipate trends in the markets. Since most cattle farmers are small producers, involvement with BQA provides the benefit of belonging to a larger organization that has access to production and market research.

$\underline{\text { Statement of the Problem }}$

The Cooperative Extension Service has offered quality programs, such as BQA, for years to different segments of the population. A quality program, however, does not ensure participation. Why do farmers not utilize the educational opportunities offered by the West Virginia Cooperative Extension Service? What keeps farmers from joining groups that provide opportunities to further their education and knowledge?

\section{Purpose of the Study}

The purpose of this study was to identify the factors that contributed to farmers' participation in the West Virginia Beef Quality Assurance program. This study explored the barriers and encouragers that affected involvement in the West Virginia Beef Quality Assurance program offered by the West Virginia Cooperative Extension Service.

\section{Objectives of the Study}

The primary objectives of this study were to:

1. Identify the demographic characteristics of participants and non-participants in the West Virginia BQA program; 
2. Identify barriers to participation in the West Virginia BQA program;

3. Identify encouragers to participation in the West Virginia BQA program; and

4. Determine benefits as seen by participants in the West Virginia BQA program.

\section{Limitations of the Study}

This study was limited to beef producers in West Virginia who were on the West Virginia Young Sire Performance Evaluation Mailing Lists.

\section{$\underline{\text { Definitions }}$}

Barrier- an obstacle that prevents one from doing a particular activity

Benefit- a positive occurrence in response to an action

Cow/calf operation-a farm that maintains a breeding herd and produces weaned calves

Encourager- something that encourages or motivates one to do a particular activity

Feeder- Cattle that need further feeding prior to slaughter

Feedlot- confined space in which cattle are fed a high a high concentrate diet prior to slaughter

Gross Income- Calculated farm income before subtracting expenses

Producer-A farmer raising beef cattle

Seedstock- Breeding Animals, (purebred)

Stocker- Weaned cattle that are fed high roughage diets before going to a feedlot 


\section{CHAPTER II:}

\section{Literature Review}

The United States Beef industry is worth an estimated 175 billion dollars, made up of more than one million businesses operating in all fifty states. In 1990, the four largest packing firms slaughtered $70 \%$ of all steers and heifers sent to market (Bailey, Bastien, Glover \& Menkhaus, 1995, $₫ 15)$. In recent years, the meat industry, including beef processing, has undergone numerous structural changes. These changes were driven by consumer demand for a leaner, more nutritive product.

The beef industry as modeled by Robert Taylor is made up of seven segments. Segment one is composed of seedstock producers, who are also known as the genetic engineers of the beef industry. They work to improve the cattle from the inside out. Segment two consists of the commercial cow-calf producers. They make up the largest segment with nearly 1 million producers involved and 180 billion dollars invested. Segment three is the yearling or "stocker" operators. Their role is to grow weaned calves on high forage or by-products for additional gains before they are shipped to feedlots. Feedlots make up the fourth segment. Feedlots are "confinement feeding operations", in which the cattle are given "finishing rations" to obtain the final weight gain needed for slaughter. At slaughter, cattle move into the packing segment, where the beef carcass is processed into sections and prepared for distribution to the retailers. The retailer processes the meat into cuts for the consumer, the seventh and final segment of the beef industry, (Taylor, 1994, pp 5-20).

Because of the complexity of the production, processing and marketing cycle, there are many places where poor judgment can adversely affect the finished product. "Each sector should assume the responsibility for the role they play in delivering a quality beef product to 
their respective markets"(Mid-Atlantic BQA, 2002, p. 3). Since the producers are the starting point in the beef industry, BQA gives the producer the skills to produce the best product possible.

The National Agricultural Statistics Service (NASS) data from the 1997 Census indicates that West Virginia had 17,772 farms. The average farm size in West Virginia was 194 acres, compared to 487 -acre national average. While the national herd average is 42 beef cows and calves, the West Virginia average was 38 . The state was reportedly already on the small side, and without help, may continue to decline as implied by "a shrinking market share and increasing carcass weights" according to Bailey et al. (1995, ๆ19).

The largest number of cattle which are produced every year and ultimately end up as an entrée somewhere, are produced on ranches of less than 200 head of cows... By and large the majority of these cattle are sold 2 or 3 at a time through an auction facility somewhere and eventually are commingled more and more until they end up in a feedlot somewhere. How these cattle are handled up to the point of sale at the auction is totally at the discretion of the producer. (Blezinger, 2002,

\section{2)}

Meat processing facilities need large quantities of beef in order to meet the needs of American consumers. In 1997, the USDA, FSIS inspected about thirty seven million cattle; which translated to approximately 64 pounds of beef per person. In the 1980's, the annual beef consumption per capita was 85 pounds (Focus on Beef, 2002). In response to decreased consumption the beef industry has taken steps to increase public awareness to the benefits of beef, in areas such as healthiness, wholesomeness and convenience. 
Modern technology that has touched life in other areas is also expected to improve the farming industry. The amount of information to which the average consumer has available, now that so many people have Internet access at home, has changed the consumer perspective. They want to know that the meat they buy is safe, and what additives it may contain.

The Beef Quality Assurance Program educates its participants so they may remain current with the market. When a buyer can be assured of the management history of cattle, a premium price at market is more likely to be obtained. An analysis by Montana State University economist Gary Brester of regular beef prices versus those of BQA calves sold in Montana found that "BQA participants received about $\$ 1.56$ more per hundredweight for steers than nonmembers and \$1.09 more per hundredweight for heifers.” (Beef Quality Assurance Program Participation Pays Off, 2002, ๆ4) This information was obtained through a survey conducted by Sweetgrass County Extension Agent Marc King.

National guidelines are set forth to assist the state coordinators in developing their programs (Beef Quality Assurance, 2001). These guidelines range from the feed and treatment of the animals, to farm record keeping. The farmer must be responsible and prove that he/she has followed these guidelines from field to feedlot. The consumer is expecting more from the producer than just palatable meat. "The level of consumer confidence in beef significantly affects their eating habits impacts the future of our industry. Consumer confidence is essential if we are to 'steak' our claim in the meat case," (Mid Atlantic BQA, 2002, p. 3).

The mission statement of the WV BQA program is "to maximize consumer confidence in, and acceptance of beef by focusing the industry's attention on BQA through the use of science, research, and education initiatives" (Mid Atlantic BQA, 2002). The BQA program addresses homogeneity of product by standardizing farming practices of its participants. This 
provides a foundation for meat history, which will be addressed in the future by identification of origins on beef products. Though origin identification is not a component of the BQA program, the BQA system of record keeping can be used as a starting point. The producers are responsible for record keeping so that their adherence to the guidelines is verifiable and good record keeping is important to good farming practices.

The BQA guidelines address areas of production such as feedstuffs, additives and medications, processing, treatments and records, injectable animal health products, husbandry and care practices. By standardizing the pre-harvest care animals receive, the buyer better is able to judge the quality of the cattle and make a purchase to benefit all involved. The NCBA's published BQA guidelines can be found in Appendix 3. Trends in the beef industry require that producers take measures to protect their position in future markets. This includes the export of beef where U.S. producers will face competition not only from themselves, but also from the lower priced imported beef from Australia and Argentina (Bailey et al, 1995, $\mid 20$ ).

These educational measures ensure that all producers involved in the program work with the same basics. The guidelines permit the producer control of their own farm while reaping the benefits afforded by the BQA certification. Stephen Blezinger said "the two most common concerns that cattlemen have about getting involved in the BQA program are uncovering a problem they would rather not deal with and the additional work or expense they might incur"(Blezinger, 2002, $₫ 12$ ). It matters little to show great results, if there is minimal participation in a certain program.

Producers can become involved to increase the safety margin around handling their cattle, for financial reasons, and to improve their product. Many producers want training to improve their herd, and BQA is a viable way in which to incorporate best management practices 
into their entire operation and address consumer concerns. Profitability is often the deciding factor in business decisions.

Beyond safety, the economic importance of BQA can be seen in the top eight challenges in the beef industry ... injection site blemishes, rib brands, excessive external fat, excessive seam fat, dark cutters, inconsistent size of meat cuts, inconsistent cuts, and non-uniform cattle. (Mid-Atlantic BQA, 2002, p. 3)

In order to create a successful adult program, the educator must identify encouragers and barriers to participation and persistence in the programs, (Norland, 1992, $\llbracket 2$ ). In her study she referred to terms that were used by Johnstone and Rivera in 1965, such as situational barriers, sociodemographic barriers, and dispositional factors. A study conducted by the Ohio State University Extension Service addressed this issue and others that were relevant to participation in programs such as BQA. Five factors emerged as principle component factors, including (1) low anticipated difficulties with arrangements, (2) high commitment to the extension organization, (3) anticipated positive social involvement, (4) anticipated high quality of the information, and (5) possession of high internal motivation to learn (Norland, 1992, q2). These factors are important contributions to the decisions to participate in any program. It is important to identify and address these issues in order to promote a successful program.

According to "Profile of the State's Agriculture," most farms are family owned and operated and the majority of these are operated by part-time farmers who maintain a full-time job off the farm, (NASS, 1997). The difficulty they experience in making time in their demanding schedules to attend workshops has directly impacted involvement in workshops and training seminars. Program organizers need to find out the community schedules and anticipate the most available times for educational meetings. Some farmers have already developed a relationship 
with the extension organization and have benefited from past programs so they are more likely to make time to participate in new or current programs. This is related to the anticipation of high quality of information. People who have already experienced the quality of extension information have some idea of the quality that is offered, since the extension service has a reputation for high quality information (Norland, 1992, $₫ 8$ ). The current participants and their status can influence the social involvement factor. Commitment to extension and the quality of the information obtained supplies paves the way for the next connection, that between the extension educator and the program participant. Clientele satisfaction is a key component to persistent program participation. Therefore a strong relationship between the program participant and the educator is important to keep participation levels high.

Summary

A need for quality control has been identified in beef production. The Extension Service, the Cattlemen's Association, and the USDA developed BQA programs to address this concern. Learning materials and training sessions have been developed and conducted across the country. All that remains is improving the participation level. By understanding the target population, communications can be tailored to directly meet the needs of producers. This is known as market segmentation, "the ability to segment your market into various groups, each of which can be provided with a unique product or communication to directly address their needs" (Bierma, Waterstraat, Kimmel, and Nowak, 1997, $₫ 33$. 


\section{CHAPTER III:}

\section{Methodology}

\section{Purpose of the Study}

The purpose of this study was to identify the factors that contributed to farmers' participation in the West Virginia Beef Quality Assurance program (BQA). This study explored the barriers and encouragers that affected involvement in the West Virginia Beef Quality Assurance program offered by the West Virginia Cooperative Extension Service.

\section{Objectives of the Study}

The primary objectives of this study were to:

1. Identify the demographic characteristics of participants and non-participants in the West Virginia BQA program;

2. Identify barriers to participation in the West Virginia BQA program;

3. Identify encouragers to participation in the West Virginia BQA program;

4. Determine benefits as seen by participants in the West Virginia BQA program.

\section{$\underline{\text { Research Design }}$}

A descriptive research design was utilized for the study that employed a telephone survey to collect data. Descriptive research techniques were appropriate for the research since the function of the survey was "to create a statistical description of the study population" (Fowler, 1988, p. 9).

\section{$\underline{\text { Methodology }}$}

The telephone survey instrument was constructed to characterize the nature of the participants and non-participants of the Beef Quality Assurance Program. Surveys are often used as tools to measure the attitudes and inclinations of the individuals involved, and provide 
"responses that are easy to administer and score" (Newsted, Huff \& Monro 1998, p. 553). Since the purpose of this study was to determine what factors determined participation of the farmer, the instrument was developed to assess differences between participants and non-participants. $\underline{\text { Population }}$

The population selected for this study was composed of 387 West Virginia beef Producers that were identified through the WV Cooperative Extension Service, and the West Virginia Cattlemen's Association. These producers were selected from the mailing list of the two West Virginia Bull Tests, since it was an established group of producers likely to include a variety of farm types and both participants and non-participants of the BQA program. The target population was derived from the original 530 names on the list after eliminating all non-residents of West Virginia. In order to create an unbiased sample list, the Statistical Package for the Social Sciences was used to select a random sample of the target population. In order to observe a medium effect size, Cohen (1984) stipulated that 85 responses to the study would be necessary. $\underline{\text { Instrumentation }}$

The survey instrument was made up of twenty-two questions with some giving the producer the opportunity to choose a best-fit answer to describe their situation. The first part of the questionnaire collected the data related to the actual farming operation with questions determining years spent farming, farm location, herd size, and breed of cattle. Also there was reference to what other livestock or field crops the producers raised. These questions were used to group the farms together by similar characteristics, to show factors on the farm that affect participation in the programs.

The next section of the questionnaire measured income of the farm and farmer. Questions regarding the farm's contribution to the farmer's income and the gross annual income 
of the farm were designed to determine common factors between the different levels of personal involvement.

The next section of the survey identified some of the barriers and encouragers that influence participation in this Extension program. This included sections intended specifically for participants or non-participants. The participants were asked why they were involved in the BQA program and what benefits they see or have seen from their participation. Non-participants were asked what the biggest barrier was to their involvement in BQA and what would encourage them to participate.

In the next part of the questionnaire, producers were asked if they had heard of the Country of Origin Labeling (COOL) initiative. This question was used to determine if they were aware of current issues in the beef industry and if the requirement of this labeling would affect their farming practice? This question was used as an indicator of their willingness to respond to market demands.

The last section of the survey was used to determine age and education level. As the final question, respondents were given the opportunity to identify anything they felt would affect participation in the WV BQA program that may not have been addressed in the previous questions. This question was analyzed using qualitative research methodology and provided insights into the farmer's feelings toward the program. See Appendix B for the complete survey. $\underline{\text { Data Collection Procedures }}$

The survey was administered through phone conversations with the producers in the spring of 2003, beginning on May $10^{\text {th }}$ and ending on June $16^{\text {th }}$. The calling hours were set for 6 p.m. until 9 p.m. on weekday evenings and for 12 p.m. to 7 p.m. on Saturdays. The researcher asked the producers if another time was more convenient for the questionnaire and some 
callbacks were made. The earliest callback was at 7 a.m., a time specified by the producer's spouse. An introduction of the researcher and the study prefaced the questioning, with the option to participate clearly given to the individual producer.

Before beginning the questionnaire, participants were assured of the confidentiality of their responses and informed of the purpose of the study along with other important information (see Appendix A). In many situations, the administrator of the survey had to convince the respondent that she was not a telemarketer. At the end of each completed survey, the researcher thanked the farmer for their help and bid them to enjoy the day or evening (according to the time). If the household no longer had cattle or that the researcher had dialed a wrong number, the call was terminated with apology for having disturbed that person.

The researcher recorded the participant's responses on a survey sheet. Once collected, all information was entered into Microsoft Excel spreadsheets for ease of comparison and to prepare the data for analysis.

Reliability was determined using the test-retest method with the pilot study. Five individuals were questioned and then re-questioned one month later. There were no differences in the responses received. Therefore, the reliability of the instrument was established.

\section{Data Analysis}

After the questionnaires have been answered, Statistical Package for the Social Sciences (SPSS) software was used to analyze the data using procedures appropriate for the data type.

\section{$\underline{\text { Use of Findings }}$}

It was hoped that the findings of this study could be used for the improvement of the West Virginia BQA program and perhaps other extension education efforts. Also, information on 
encouragers and barriers to participation will aid in the development of better attendance to existing and future extension programs. 


\section{CHAPTER IV:}

\section{Findings}

\section{Purpose of the Study}

The purpose of this study was to identify the factors that contributed to farmers' participation in the West Virginia Beef Quality Assurance (BQA) program. This study explored the barriers and encouragers that affected involvement in the West Virginia Beef Quality Assurance program offered by the West Virginia Cooperative Extension Service.

\section{Objectives of the Study}

The primary objectives of this study were to:

1. Identify the demographic characteristics of participants and non-participants in the West Virginia BQA program;

2. Identify barriers to participation in the West Virginia BQA program;

3. Identify encouragers to participation in the West Virginia BQA program; and

4. Determine benefits as seen by participants in the West Virginia BQA program.

\section{$\underline{\text { Findings }}$}

The data for this study were collected using a telephone survey conducted in May and June of 2003. Eighty-five West Virginia beef producers responded to the questionnaire and were divided into groups of participants and non-participants in the program. The respondents were asked to answer questions that would provide information to answer the stated objectives of describing the demographic characteristics of participants and non-participants in the BQA program, identify barriers and encouragers to participation, and to determine what benefits that participants feel that they receive from being associated with BQA. 


\section{$\underline{\text { Demographics }}$}

The demographic characteristics of the producers were described by the categories of age, years spent farming, education level, size of herd, income, and other items pertaining to the individual's situation. The average age of the respondents to the survey was 54.2 yrs, with a standard deviation of 14.5 years. Approximately $68 \%$ of the farmers questioned fell between the ages of 40 and 68 . The average number of years spent farming was found to be 34.4 years

Non-participants of BQA had a mean age of 55.4 and had an average of 34.3 years farming. The mode education level for non-participants was high school graduate. The farm income made up $34 \%$ of the household income. Twenty-six percent of non-participants credit farming as the primary income of the household. The average gross farm income was calculated to be $\$ 57,517$.

The average age for a BQA participant was 51.9 years and the average years spent farming was 35.5. The mean herd size was 87 head of brood cows. BQA producers had a mode education level of a college degree. Forty percent of the household income was identified as coming from the farm. Only $28 \%$ of the BQA producers cited farming as the household's primary source of income. The average gross farm income for BQA participants was $\$ 88,607$ Table 1 Demographic Characteristics of West Virginia Beef Farmers

\begin{tabular}{lccc}
\hline \multicolumn{1}{c}{ Characteristic } & Non- BQA Participant & BQA Participant & \multicolumn{2}{c}{ Overall } \\
& \multicolumn{1}{c}{$X$} & $X$ & $X$ \\
\hline Age of Farmer & 55.4 & 51.9 & 54.2 \\
Years Farming & 34.3 & 35.5 & 34.4 \\
Herd Size & 70.0 & 87.0 & 76.0 \\
\% Income & 34.0 & 40.0 & 37.0 \\
Primary income Farming & 26.0 & 28.0 & 27.0 \\
Gross Farm Income & $\$ 57,517$ & $\$ 88,607$ & $\$ 70,000$ \\
\hline
\end{tabular}


Question 21 of the survey was designed to determine the highest level of education completed by the producers. Education levels ranged from less than high school, to greater than a master's degree. For the entire group of respondents, $7.1 \%$ of the farmers had less than a high school education. The largest number, 32 (37.6\%), of respondents had a high school diploma or GED (graduate equivalency diploma). Fourteen (16.5\%) respondents had a bachelor's degree. Only $12(14.2 \%)$ of the respondents had more than a bachelor's degree.

Twenty-four (45.3\%) non-participants of the BQA program had completed their high school education while $7.5 \%(\mathrm{n}=4)$ had less than a high school diploma. Eleven $(20.8 \%)$ had some college, while $18.9 \%(\mathrm{n}=10)$ had a bachelor's degree. Four $(7.5 \%)$ non-participants had more than a bachelor's degree and half of those $(n=2)$ had completed a master's degree.

Participants of the BQA program had the lowest percent, $6.3 \%(n=2)$, of people with an education of less than high school. Most of the participants had some level of college education with $31.3 \%(\mathrm{n}=10)$ of the respondents having attended some institution after high school. Twelve BQA producers (37.2\%) have earned a college degree (see Table 2).

Table 2

Educational level of WV Beef Farmers

\begin{tabular}{|c|c|c|c|c|c|c|}
\hline \multirow[b]{2}{*}{ Characteristic } & \multicolumn{2}{|c|}{$\begin{array}{l}\text { Non-BQA } \\
\text { Participant }\end{array}$} & \multicolumn{2}{|c|}{ BQA Participant } & \multicolumn{2}{|c|}{ Overall } \\
\hline & $N$ & $\%$ & $N$ & $\%$ & $N$ & $\%$ \\
\hline \multicolumn{7}{|l|}{ Education Level } \\
\hline Less than High School & 4 & 7.5 & 2 & 6.3 & 6 & 7.1 \\
\hline High School * & 24 & 45.3 & 8 & 25.0 & 32 & 37.6 \\
\hline Some College** & 11 & 20.8 & 10 & 31.3 & 21 & 24.7 \\
\hline College Degree*** & 14 & 26.6 & 12 & 37.2 & 26 & 31.2 \\
\hline
\end{tabular}

* Graduate Equivalency Diploma (GED) was recorded as High School Completion

** Associate's degrees and Technical School training were recorded as Some College *** College Degree included Bachelor's degrees and beyond. 
The West Virginia beef producers surveyed were from many different areas of the state. Twenty-five farmers were from the eastern panhandle in Hampshire, Hardy, Grant, Berkeley, Jefferson, and Mineral counties. The north central region with the counties of Monongalia, Marion, Barbour, Preston, Taylor, Harrison, Doddridge, Tucker, and Tyler had 27 farmers in this study. The eastern counties included Pendleton, Randolph, Pocahontas, Greenbrier, and Monroe with 12 farmers responding to the survey. The northwestern region consisted of 2 farmers from Wood and Pleasants counties. Central West Virginia included 19 producers from Gilmer, Lewis, Upshur, Roane, Clay, and Braxton counties. The southwestern and south-central portions of the state were not represented in the survey. See Appendix F for county distribution.

West Virginia beef producers raised a variety of breeds in their operations. The predominant breed, Angus or Angus crossed cattle, were raised by $70 \%$ of producers. The reason for the overlapping numbers was due to many farmers raising purebred cattle, raised more than one breed. Many of the Angus seedstock producers, also raised commercial crossbred cattle.

Table 3

Cattle Breeds Raised by WV Producers

\begin{tabular}{|c|c|c|c|c|c|c|}
\hline \multirow[b]{2}{*}{ Characteristic } & \multicolumn{2}{|c|}{$\begin{array}{c}\text { Non Participant } \\
\text { BQA }\end{array}$} & \multicolumn{2}{|c|}{$\begin{array}{c}\text { Participant } \\
\text { BQA }\end{array}$} & \multicolumn{2}{|c|}{ Overall } \\
\hline & $\mathrm{N}$ & $\%$ & $\mathrm{~N}$ & $\%$ & $\mathrm{~N}$ & $\%$ \\
\hline \multicolumn{7}{|l|}{ Breed } \\
\hline Angus & 38 & 71.7 & 22 & 68.8 & 60 & 70.6 \\
\hline Hereford & 4 & 7.5 & 2 & 6.3 & 6 & 7.1 \\
\hline Charolais & 4 & 7.5 & 1 & 3.1 & 5 & 5.9 \\
\hline X-Breed* & 20 & 37.7 & 20 & 62.5 & 40 & 47.1 \\
\hline Other** & 2 & 3.8 & 5 & 15.7 & 5 & 5.9 \\
\hline
\end{tabular}

* Many people who raised X-breed cattle also raised purebred Angus calves therefore some people were in more than one category

** Other includes Simmental, Buffalo, \& Brangus 
Many West Virginia beef producers (88.2\%) managed cow-calf herds. Seed stock producers were rare in the state $(n=3,3.5 \%)$. There were a few stockers and feeders $(n=2327.0$ $\%)$ to complete the producer types. Most producers involved in stocker or feeder programs do so as a means of retaining ownership or to utilize surplus forage along with their cow-calf herd.

Non-participants of BQA were very similar to the overall picture of the West Virginia Beef producer in herd-type classification with 44 producers $(83 \%)$ having a cow/calf operation. Thirteen $(24.5 \%)$ of the farmers raised feeder or stocker calves. The only three seed stock producers in the study $(5.7 \%)$ were not involved with the BQA program.

Participants of the BQA program were involved in cow/calf operations $(96.9 \%, n=31)$. No seedstock producers interviewed were involved in BQA. The feeder and stocker segments of BQA participants involved $31.3 \%(n=10)$ of the group (see Table 4$)$.

Table 4

Type Herd Raised by WV Producers

\begin{tabular}{|c|c|c|c|c|c|c|}
\hline \multirow[b]{2}{*}{ Characteristic } & \multicolumn{2}{|c|}{$\begin{array}{c}\text { Non Participant } \\
\text { BQA }\end{array}$} & \multicolumn{2}{|c|}{$\begin{array}{c}\text { Participant } \\
\text { BQA }\end{array}$} & \multicolumn{2}{|c|}{ Overall } \\
\hline & $\mathrm{N}$ & $\%$ & $\overline{\mathrm{N}}$ & $\%$ & $\mathrm{~N}$ & $\%$ \\
\hline \multicolumn{7}{|l|}{ Herd Type } \\
\hline Cow/Calf & 44 & 83.0 & 31 & 96.9 & 75 & 88.2 \\
\hline Stocker \& Feeder* & 13 & 24.5 & 10 & 31.3 & 23 & 27.0 \\
\hline Seed Stock & 3 & 5.7 & 0 & 0.0 & 3 & 3.5 \\
\hline
\end{tabular}

*Some of the feeder and stocker farmers raised their own calves and fed them up until feedlot sale or slaughter.

Cattle producers in West Virginia were not limited to beef animals. Question 3 of the survey asked these farmers what other classes of livestock they raised. Overall, most of the farmers concentrated on cattle and had no other livestock $(61.2 \%, \mathrm{n}=52)$. Horses, donkeys and mules were raised by 16 producers, $(19.2 \%)$, and $12.0 \%(n=10)$ raised poultry. Sheep and goats were third highest in production with $17.7 \%(\mathrm{n}=15)$ producers having them on their farms. 
Non-participants of BQA were most likely to only raise cattle as $66 \%(n=35)$ of those surveyed raised no other livestock. Horses donkeys and mules were the next popular animals with $22.7 \%(n=12)$ of the non-BQA producers indicating that they raised horses. Eight producers $(15.1 \%)$ raised sheep and goats, while six $(11.3 \%)$ of the non-BQA producers surveyed raised poultry. (see Table 5)

BQA participants had little variety within the overall sample with $53.1 \%(n=17)$ raising only beef cattle. Four other types of livestock were mentioned. Seven (21.9\%) raised sheep along with the cattle on their farms.

Table 5

Livestock Raised by West Virginia Beef Farmers

\begin{tabular}{|c|c|c|c|c|c|c|}
\hline \multirow[b]{2}{*}{ Characteristic } & \multicolumn{2}{|c|}{$\begin{array}{c}\text { Non Participant } \\
\text { BQA }\end{array}$} & \multicolumn{2}{|c|}{$\begin{array}{l}\text { Participant } \\
\text { BOA }\end{array}$} & \multicolumn{2}{|c|}{ Overall } \\
\hline & $\mathrm{N}$ & $\%$ & $\mathrm{~N}$ & $\%$ & $\mathrm{~N}$ & $\%$ \\
\hline \multicolumn{7}{|l|}{ Livestock Animal } \\
\hline Cattle Only & 35 & 66.0 & 17 & 53.1 & 52 & 61.2 \\
\hline Horses, Donkeys \& Mules & 12 & 22.7 & 4 & 12.5 & 16 & 19.2 \\
\hline Sheep \& Goats & 8 & 15.1 & 7 & 21.9 & 15 & 17.7 \\
\hline Poultry* & 6 & 11.3 & 4 & 12.5 & 10 & 12.0 \\
\hline Pigs & 3 & 5.7 & 3 & 9.4 & 6 & 7.1 \\
\hline
\end{tabular}

* Includes chickens and turkeys

Question 7 of the survey was designed to determine what field crops producers grew. Hay was raised by most producers surveyed $(94.1 \%, n=80)$. Twenty-two $(25.9 \%)$ farmers grew corn making it the second highest grown crop. Of the 6 other crops, no more than $5.8 \%(n=5)$ of producers raised any one of them.

Of the non-BQA members, $92.5 \%(n=49)$ raised hay as a field crop. Twelve $(22.6 \%)$ raised corn. The other categories had very low percentages. There was only one farmer who did not raise any field crops. 
Almost all of the West Virginia BQA producers surveyed $(96.9 \%, n=31)$ raised hay. Corn was raised by $31.3 \%(n=10)$. Soybeans and barley were each raised by $9.4 \%(n=3)$ of the farmers surveyed. The other crops were raised only by a few producers each (see Table 6).

Table 6

Crops Grown by Farmers

\begin{tabular}{|c|c|c|c|c|c|c|}
\hline \multirow[b]{2}{*}{ Characteristic } & \multicolumn{2}{|c|}{$\begin{array}{c}\text { Non Member } \\
\text { BQA }\end{array}$} & \multicolumn{2}{|c|}{$\begin{array}{c}\text { Participant } \\
\text { BQA }\end{array}$} & \multicolumn{2}{|c|}{ Overall } \\
\hline & $\mathrm{N}$ & $\%$ & $\mathrm{~N}$ & $\%$ & $\mathrm{~N}$ & $\%$ \\
\hline \multicolumn{7}{|l|}{ Field Crop* } \\
\hline None & 1 & 1.9 & 1 & 3.1 & 2 & 2.4 \\
\hline Corn & 12 & 22.6 & 10 & 31.3 & 22 & 25.9 \\
\hline Hay & 49 & 92.5 & 31 & 96.9 & 80 & 94.1 \\
\hline Soybean & 1 & 1.9 & 3 & 9.4 & 4 & 4.7 \\
\hline Oats & 3 & 5.7 & 0 & 0.0 & 3 & 3.5 \\
\hline Alfalfa & 1 & 1.9 & 1 & 3.1 & 2 & 2.4 \\
\hline Barley & 2 & 3.8 & 3 & 9.4 & 5 & 5.8 \\
\hline Grass & 1 & 1.9 & 0 & 0.0 & 1 & 1.2 \\
\hline Sorghum & 0 & 0.0 & 1 & 3.1 & 1 & 1.2 \\
\hline Sudex (a hybrid) & 1 & 1.9 & 0 & 0.0 & 1 & 1.2 \\
\hline Wheat & 2 & 3.8 & 1 & 3.1 & 3 & 3.5 \\
\hline
\end{tabular}

*Many farmers reported growing more than one field crop

Question 11 of the survey determined how West Virginia farmers learned new techniques for their operations. The West Virginia University Extension service, with $81.2 \%(n=69)$ of the population, was the most popular source. Magazines were identified by $73 \%(n=62)$ of farmers as a source of information. Books were the third most popular source of information with $42.4 \%$ $(n=36)$ of the population reporting the use of them. A small contingent of farmers $(20 \%, n=17)$, used technology and utilized the Internet as an information source, See Table 7 for other methods of obtaining information.

Non-participants of the BQA program utilized magazines and Extension Service as their top choices for information sources with $73.7 \%(n=39)$ and $71.7 \%(n=38)$ of the population 
reporting their use, respectively. Books were credited as a source by $39.6 \%(n=21)$ of the producers. See Table 7 for other methods of obtaining information.

BQA producers utilized their Extension agents $(n=31,96.9 \%)$ as a source of information. Magazines were used by $71.9 \%(n=23)$ of the BQA producers to learn new techniques. Books $(46.9 \%, n=15)$ were third in usage to gather information. The Internet with $25 \%(n=8)$ use was most popular with this group when compared to non-participants. See Table 7 for other categories and values.

Table 7

Where Farmers Obtain New Information for their Operations

\begin{tabular}{|c|c|c|c|c|c|c|}
\hline \multirow[b]{2}{*}{ Characteristic } & \multicolumn{2}{|c|}{$\begin{array}{c}\text { Non Participant } \\
\text { BQA }\end{array}$} & \multicolumn{2}{|c|}{$\begin{array}{l}\text { Participant } \\
\text { BQA }\end{array}$} & \multicolumn{2}{|c|}{ Overall } \\
\hline & $\mathrm{N}$ & $\%$ & $\mathrm{~N}$ & $\%$ & $\mathrm{~N}$ & $\%$ \\
\hline \multicolumn{7}{|l|}{ Media } \\
\hline Extension Service & 38 & 71.7 & 31 & 96.9 & 69 & 81.2 \\
\hline Books & 21 & 39.6 & 15 & 46.9 & 36 & 42.4 \\
\hline Magazines & 39 & 73.7 & 23 & 71.9 & 62 & 73.0 \\
\hline Internet & 9 & 17.0 & 8 & 25.0 & 17 & 20.0 \\
\hline Experience & 3 & 5.7 & 0 & 0.0 & 3 & 3.5 \\
\hline NRCS & 5 & 9.4 & 1 & 3.1 & 6 & 7.1 \\
\hline Other* & 9 & 17.0 & 4 & 12.5 & 13 & 15.6 \\
\hline
\end{tabular}

*including peers, the Farm Bureau, feed store, government, meetings, television, USDA, veterinarian, workshops, and The Wall Street Journal as sources of information.

Questions $18 \& 19$ were included to give a measure of knowledge on current issues facing beef producers. Knowledge of Country of Origin Labeling (COOL) was selected to evaluate this concept. Overall $57.6 \%(n=49)$ of the producers had heard of COOL. Only $45.3 \%$ $(n=24)$ of the non-participants had heard of COOL, while 78.1\% $(n=25)$ of the BQA participants had heard of the program.

Participants were asked the amount of change to the farm that COOL requirement would cause to assess the quality of record keeping that currently occurred on the farm. Generally, $73 \%$ 
$(n=62)$ of the producers questioned felt that it would either not affect their business at all or very little. Nineteen (22.4\%) farmers saw the need for moderate change, while $4.7 \%(n=4)$ of the producers believed that this type of requirement would constitute many changes on their farms.

The majority of non-BQA participants saw COOL requirement as requiring change in their operations with $73.6 \%(\mathrm{n}=39)$ feeling that little or moderate change would be necessary. Only $18.9 \%$ of the producers $(n=10)$ felt that they would not need to change, while the only 4 producers $(7.5 \%)$ who felt that this would require a lot of change in their operations were not involved with the BQA program.

Participants of the BQA program felt that COOL requirement would not affect any of them greatly. Most of the BQA members, $50 \%(\mathrm{n}=16)$ did not foresee having to change anything about their operations, and another $40.6 \%(\mathrm{n}=13)$ felt that very little change would be involved. There were no participants of BQA who felt that it would require a lot of change on their farms. Table 8

WV Producers Knowledge of Country of Origin Labeling (COOL) and Amount of Effect on Operation

\begin{tabular}{|c|c|c|c|c|c|c|}
\hline \multirow[b]{2}{*}{ Characteristic } & \multicolumn{2}{|c|}{$\begin{array}{c}\text { Non Participant } \\
\text { BQA }\end{array}$} & \multicolumn{2}{|c|}{$\begin{array}{c}\text { Participant } \\
\text { BQA }\end{array}$} & \multicolumn{2}{|c|}{ Overall } \\
\hline & $\mathrm{N}$ & $\%$ & $\mathrm{~N}$ & $\%$ & $\mathrm{~N}$ & $\%$ \\
\hline COOL Knowledge & 24 & 45.3 & 25 & 78.1 & 49 & 57.6 \\
\hline Amount of Change & & & & & & \\
\hline Not at All & 10 & 18.9 & 16 & 50.0 & 26 & 30.6 \\
\hline Very Little & 23 & 43.4 & 13 & 40.6 & 36 & 42.4 \\
\hline Moderately & 16 & 30.2 & 3 & 9.4 & 19 & 22.4 \\
\hline Very Much & 4 & 7.5 & 0 & 0.0 & 4 & 4.7 \\
\hline
\end{tabular}

Question 12 of the survey examined how farmers were informed of the BQA program. Overall $78.8 \%(\mathrm{n}=67)$ of producers surveyed had heard of the BQA program. Most of these 
$(49.4 \%, n=42)$ heard of it through the West Virginia University Extension service. The West Virginia Cattlemen's Association informed another 31.8\% $(n=27)$, with the remaining $10.6 \%$ $(n=9)$ hearing about it from an auction or their peers (other farmers).

Of the non-participants surveyed, 35 producers $(66 \%)$ had heard of the BQA Program. The Extension Service and the Cattlemen's Association were responsible for the largest portion of this knowledge with each having over $35 \%$ of respondents crediting them with having informed them. Refer to Table 9 for other ways that non-participants heard of the BQA program.

Participants of the BQA program all had to have heard of the program to be involved in it. Extension was responsible for the majority $(71.9 \%, n=23)$ of these respondents knowledge of the program. The livestock markets and the West Virginia Cattlemen's Association informed another $37.5 \%(n=12)$ while another $6.3 \%(n=2)$ producers heard of the program from other farmers.

Table 9

Knowledge of BQA Program and Source

\begin{tabular}{|c|c|c|c|c|c|c|}
\hline \multirow[b]{2}{*}{ Characteristic } & \multicolumn{2}{|c|}{$\begin{array}{c}\text { Non Participant } \\
\text { BQA }\end{array}$} & \multicolumn{2}{|c|}{$\begin{array}{l}\text { Participant } \\
\text { BQA }\end{array}$} & \multicolumn{2}{|c|}{ Overall } \\
\hline & $\mathrm{N}$ & $\%$ & $\mathrm{~N}$ & $\%$ & $\mathrm{~N}$ & $\%$ \\
\hline Knowledge of BQA & 35 & 66.0 & 32 & 100 & 67 & 78.8 \\
\hline \multicolumn{7}{|l|}{ Source } \\
\hline Extension* & 19 & 35.8 & 23 & 71.9 & 42 & 49.4 \\
\hline Auction & 1 & 1.9 & 5 & 15.6 & 6 & 7.1 \\
\hline Cattlemen's Association* & 20 & 37.7 & 7 & 21.9 & 27 & 31.8 \\
\hline Peers & 1 & 1.9 & 2 & 6.3 & 3 & 3.5 \\
\hline
\end{tabular}

* Many producers had heard of BQA through both the West Virginia Cattlemen's Association and the West Virginia University Extension Service 


\section{$\underline{\text { Barriers }}$}

Question 14 dealt with the barriers that farmers experience in becoming involved with the BQA program. Not having time was the largest barrier expressed by non-participants $(39.6 \%$, $\mathrm{n}=21)$ preventing participation in BQA. A lack of program awareness kept $30.2 \%(n=16)$ of the sample from participating. Another $28.3 \%$ held that it simply was not convenient for them to be involved with BQA. Other less popular reasons are reported with Table 10.

Table 10

Barriers to Participation in WV BQA Program

\begin{tabular}{lrr}
\hline & \multicolumn{3}{c}{ Non Participant BQA } \\
\cline { 2 - 3 } Characteristic & $\mathrm{N}$ & $\%$ \\
\hline Barrier & 21 & 39.6 \\
Time & 4 & 7.5 \\
Money & 15 & 28.3 \\
Convenience & 16 & 30.2 \\
Unaware of BQA & 11 & 20.8 \\
Other* & &
\end{tabular}

*Included retirement, a strong dislike of being told what to do, different interests, no market requirement for BQA, and a beef operation that was not compatible with the BQA ideal (stockers and feeders)

$\underline{\text { Encouragers }}$

Question 15 asked the non-participants what might encourage them to participate in the program. The two largest response categories were location $(24.5 \%, n=13)$ and program awareness $(24.5 \%, n=13)$. Six $(11.3 \%)$ of the non-participants said that BQA was not applicable to their operations or they would consider it. A few said if being BQA certified would help them with COOL compliance, then they would participate. Other encouragers can be seen in Table 11. 
Table 11

Encouragers to Participation in WV BQA Program

\begin{tabular}{lrr}
\hline & \multicolumn{2}{c}{ Non Participant BQA } \\
\cline { 2 - 3 } Characteristic & $\mathrm{N}$ & $\%$ \\
\hline Encourager & 5 & \\
Different Meeting time & 13 & 24.4 \\
Location & 4 & 7.5 \\
COOL Compliance & 13 & 24.5 \\
Awareness of Program & 6 & 11.3 \\
Inapplicable to Operation & 8 & 15.0 \\
Other* & &
\end{tabular}

* Included a change in the program to make it suitable for their operations (feeders and stockers) would encourage participation, as would more public information about the program

$\underline{\text { Reasons }}$

Question 16 asked participants of the BQA program to state why they were involved. The largest group $(37.5 \%, \mathrm{n}=12)$ declared that marketing brought them into the program. Almost as popular an answer was new techniques with $(34.4 \%, \mathrm{n}=11)$. Four $(12.5 \%)$ had good experiences with extension programs and therefore participated in relevant extension programs for their operation. Other reasons can be seen in Table 12.

Table 12

Reasons for Participating in WV BQA Program

\begin{tabular}{lcc}
\hline & \multicolumn{2}{c}{$\begin{array}{c}\text { Participant } \\
\text { BQA }\end{array}$} \\
\cline { 2 - 3 } Characteristic & $\mathrm{N}$ & 34.4 \\
\hline Why & 11 & 37.5 \\
New Techniques & 12 & 12.5 \\
Marketing & 4 & 21.7 \\
Quality Extension Program & 7 & \\
Other* & & \\
&
\end{tabular}




\section{$\underline{\text { Benefits }}$}

Question 17 asked BQA producers what benefits they saw from their involvement in the program. Improved prices were cited by $68.8 \%(n=22)$ of the participants as a benefit to the program. Marketing of their animals was a benefit important to $25 \%(n=8)$ of the participant. Carcass data and the improved product that BQA helped them to produce were seen as a benefit by another $15.7 \%(n=5)$ of participants.

Table 13

Benefits Seen to Participating in WV BQA Program

\begin{tabular}{lrr}
\hline & \multicolumn{2}{c}{$\begin{array}{c}\text { Participant } \\
\text { BQA }\end{array}$} \\
\cline { 2 - 3 } Characteristic & $\mathrm{N}$ & $\%$ \\
\hline Benefit & 22 & 68.8 \\
$\quad$ Prices & 8 & 25.0 \\
Marketing & 3 & 9.4 \\
Improved product & 2 & 6.3 \\
Carcass Data & 5 & 15.5 \\
Other* & & \\
\hline
\end{tabular}

* Included in survey responses were pooling cattle for sales, seeing other farming operations, and a high belief in the BQA mission.

Qualitative Response

Question 22 of the survey demonstrated a lack of understanding about the BQA program. Producers made comments that indicated their misconceptions about BQA. Inaccurate information about BQA was evident in comments such as:

- It seems like a good program, but it is not practical for this (stocker) operation.

- Certain markets do not benefit from BQA procedures, some growers have contracts with packers who want animals with no hormones or antibiotics, BQA does not have a program for herd health for this type of producers 
- I don't want them telling me what I have to raise and do to the cattle on my farm.

- The BQA program is too much work for the benefits that may be seen.

There were also misconceptions about the program from producers who were already involved. They provided responses that pertained to the BQA marketing program, which is separate from the training program. Producers who wish to participate in the marketing program must complete the BQA training, but BQA producers do not have to be involved in the BQA certified sales.

- Takes the wait out of graded sale weigh in time.

- Also many producers listed marketing as a benefit to involvement to BQA. The marketing benefits come with the BQA marketing pools, not the producer education and certification.

Producers also had comments on their satisfaction with the West Virginia BQA program. They gave affirmations about how the program was helpful and that it was the future of the industry.

- It's a pretty good program.

- People need to understand how the BQA program can affect their herd and the industry then it will be easier to get participation.

- Those who know it, use it, it is tough to reach the backyard farmers who just grow a few...

- A wonderful program that increases the quality of our cattle.

- It is the future of the cattle industry, once the consumer knows that some cattle are better than others at the farm level and that this can follow them to market, producers will be rewarded for their perseverance to technologically better herd care. 


\section{CHAPTER V:}

\section{Summary, Conclusions, and Recommendations}

\section{Purpose of the Study}

The purpose of this study was to identify the factors that contributed to farmers' participation in the West Virginia Beef Quality Assurance program. This study explored the barriers and encouragers that affected involvement in the West Virginia Beef Quality Assurance program offered by the West Virginia Cooperative Extension Service.

\section{Objectives of the study}

The primary objectives of this study were to:

1. Identify the demographic characteristics of participants and non-participants in the West Virginia BQA program;

2. Identify barriers to participation in the West Virginia BQA program;

3. Identify encouragers to participation in the West Virginia BQA program; and

4. Determine benefits as seen by participants in the West Virginia BQA program.

\section{$\underline{\text { Research Design }}$}

A descriptive research design that utilized a survey as the data collection instrument was used for the research study. The survey was constructed to determine the nature of the participants and non-participants of the Beef Quality Assurance Program. $\underline{\text { Population }}$

The population selected for this study was composed of West Virginia Beef Producers that were identified through the West Virginia Cooperative Extension Service and the West Virginia Cattlemen's Association. These producers were selected from the mailing list of the two West Virginia Young Sire Evaluation Programs. The population contained 387 West 
Virginia Beef producers that were on the mailing list. A random sampling of these producers was taken to form the survey population using the Statistical Package for the Social Sciences in order to create an unbiased sample list. In order to observe a medium effect size, Cohen (1984) stipulated that 85 responses to the study would be necessary. So the final sample included 85 producers comprised of 32 BQA participants and 56 non-participants.

Conclusions

The average West Virginia beef farmer has a high school education, has an $88.2 \%$ chance of having a cow/calf herd of mostly Angus cattle with about 75 head of brood cows, and raises hay on their farms (94.1\%). The average producer has been in the business for 34.4 years and the majority surveyed raised cattle only, (61.2\%). It was shown in Chapter IV that while 78.8\% had heard of the BQA program, only $37.6 \%$ have become involved. They were most likely to get new information on farming techniques from the Extension Service (81.2\%) and magazines $(73 \%)$.

Participants in the BQA program had a college degree, were an average of 51.9 years of age, and had a larger herd size ( 87 brood animals) than non-participants. Their gross farm income averaged $\$ 88,607$, and made up a larger percentage of their household income. Nonparticipants in the BQA Program kept a herd size of about 70 brood animals and had about $\$ 57,517$ per year of gross farm income. BQA producers reported $\$ 31,000$ more income from the farm than non-BQA producers. Most of their new information came from the Extension Service and magazines.

By asking the producers to identify the barriers to participation in a program, coordinators have gained information to use for program improvement. Given the choices of time, money and convenience, producers chose time as their main difficulty. Failure to 
understand the concepts and benefits of the BQA program provided a reason to not participate in training sessions.

Non-participants expressed convenience as another barrier that prevented their involvement due to location of meetings and training sessions. They were unwilling to travel very far to attend the educational seminars. Producers also expressed an unwillingness to change their operation.

Some farmers were simply not interested in BQA because they claimed that it did not apply to their operation. Some producers ran stockers and feeders on their farms, a couple had an agreement with a local slaughterhouse and fed all cattle up to slaughter and sold to a specialty market, therefore did not feel that BQA was relevant to their operation. While a some producers were contracted to produce beef with special characteristics such as no hormones or antibiotics, or limited exposure to certain vaccines or pesticides. These producers represented a misunderstanding that the farming community has about the BQA program. Since the BQA education program is a series of best management practices, it can apply to any operation, because management is critical to sound production and business. It is ultimately up to the producer to decide what is best for his/her herd. BQA does not interfere with those decisions.

When asked what encouragers would motivate them to participate, locations of the meetings or seminars were an issue. Many of the producers indicated trip of more than 2 hours to get to a training session with no local meetings to interest them in the program to begin with.

Program awareness was identified as an encourager to participation in the BQA program. The survey was the first time that 18 of the 85 farmers had heard of BQA. Many of them expressed a keen interest in BQA, yet had not been approached about it in the past. The relationship the farmers had with their local extension agent factored into this because some 
producers tried their best to avoid speaking to extension, citing personal differences, so they were unwilling to utilize the services that were already in place. Knowledge of BQA came about in many ways; the West Virginia Extension Service and the West Virginia Cattlemen's Association are responsible for most of the knowledge of the BQA program. Almost 50\% of all producers who have heard of BQA heard about it from the Extension Service, another 32\% of them heard about it through the West Virginia Cattlemen's Association (see Table 10).

BQA faces the problem of a misconception that producers both participants and nonparticipants have about the program. The responses that produces provided to several of the questions such as why they were involved in BQA, what the benefits they received, and the barriers and encouragers to participation all indicated that there exists a misunderstanding of the program itself and its purpose for the producers involved. This shows that even though people might think that it is a good or bad program, they don't really know what it is.

The consumer side of the beef industry also needs to be aware of BQA. One farmer commented "if we can get awareness out there to both the producers and the consumer, the feedlots and packing firms would have a reason to demand BQA certified animals." A demand from buyers would bolster the market incentives for BQA certified animals, and market incentives are a great way to convince producers to participate in a program.

A few of the farmers said that awareness needed to be expanded in quality, though the name of the program may be known, but in some cases, there is little substance to back up the name. One producer stated, "Once farmers understand how the BQA program can affect their herd and the industry as a whole, it will be easier to get their participation." In marketing, this is referred to as "Inform and Evaluate," where specific information on the innovation or program is sent out, including stories on the successes of others involved. (Bierma et al. 1997, ๆ. 16) 
The average producer that is involved with the BQA program makes more money per year from his/her operation and is able to keep a larger herd, than non-participants. The West Virginia BQA program is still getting established with the producers. As word of the program spreads, participation will increase. BQA could become a universal standard for the industry if pitched to the right people

Those producers already involved in the BQA program identified the benefits associated with the program, these were marketing, prices, carcass data, and more. Marketing is important to farmers, they have a product that needs buyers, positive marketing helps toward that goal. Most people want to improve their product, BQA offers a proven method for improving the herd. Some producers said that they are in the BQA program for the premiums they get at market for their cattle.

\section{$\underline{\text { Recommendations }}$}

The BQA certification program is still a new program, and our challenge is convincing producers that it is worth their time and effort to participate. This suggests that a more aggressive and informative advertising campaign. This should include those media that producers mentioned as sources for new techniques such as the Natural Resource Conservation Service (NRCS). Also, a nationwide consumer education program on the advantages of BQA would give producers the edge when dealing with the public since they would be prepared to explain the importance of safety in their operations.

Sections of the beef market do not feel that BQA applies to them enough for the producers in these segments to consider it a worthwhile venture. The seed stock producers, farmers who run stockers and feeders, need to be pursued with a different type of publicity. While specialized producers and their contract companies should be addressed with another type. 
Such producers would still benefit from the best management practices such as technique and handling practices that the BQA program teaches. Marketing that is tailored to a diverse population of producers would yield higher participation rates in the programs future.

One of the producers that I spoke with felt that the BQA program should be mandatory, another didn't want the government interfering on his farm, but the comments of another created a possible solution to this dilemma. She suggested that the government already does many farm assistance programs, maybe a BQA requirement should be attached to assistance so that regulations could protect the interests involved.

Extension programming is only as good as the audiences that it reaches. BQA is showing that it is reaching some, but there are many that are ready to listen, they just need a nudge to understand that they need it. The BQA program is a product that can be marketed successfully to the West Virginia beef producers. This can be addressed by "emphasizing the different aspects" of the program, (Bierma et al, 1997, $\llbracket 3$ ).

$\underline{\text { Suggestions for Further Research }}$

Further Research should be undertaken to broaden the knowledge of factors that influence participation in Extension programming. Some areas that should be looked into are:

- Investigation of the alternative beef producers, including seedstock producers, stockers and feeders, and those catering to specialized contracts, and how they can be approached with the BQA program.

- A sampling of producers from each county in West Virginia would create a more detailed picture of West Virginia beef producers.

- This study should be recreated in another state and to findings compared. 
- The differences in the characteristics of innovators, early adopters, early majority, late majority, and laggards (Bierma et al. 1997, ๆ 7) would prove useful in separating out the parts of the population that are the most difficult to reach, and may help identify what could motivate the later groups. This could identify the segments of advertising about the BQA program that is attracting producers so that the Extension can make the most of their advertising budget.

- A marketing study on BQA prices compared to non-BQA prices will provide hard evidence to possible participants about the benefits of BQA.

- Producer retention should be studied in the BQA program over time. 


\section{REFERENCES}

Alreck, P., \& Settle, R. (1995). The survey research handbook. ( $2^{\text {nd }}$ ed.). Illinois: Irwin Professional Publishing.

Bailey, D., Bastien, C., Menkhaus, D.J., \& Glover, T. F. (1995). The role of Cooperative Extension in the Changing Meat Industry. Journal of Extension, 33(4) Retrieved January 22, 2003 from http://www.joe.org/joe/1995august/a2.html.

Bierma, T.J., Waterstraat, F.L., Kimmel, G., \& Nowak, P. Jr., (1997). If it Sells Soap It can Help Sell Innovations: A Useful Lesson in Marketing. Journal of Extension, 35(5) Retrieved February 25, 2003 from http://www.joe.org/joe/1997october/a2.html

Beef Quality Assurance. (n.d.). Retrieved July 23, 2002, from http://www.bqa.org.

Beef Quality Assurance Program Participation Pays Off. (2002, February 6). MSU University News, Retrieved January 20, 2003, from http://www.montana.edu/commserv/csnews/nwview.php?article=66.

Blezinger, S. (2002). Assuring quality for beef consumers an important part of every producer's operation. Cattle Today. Retrieved 1/20/2003 from http://www.cattletoday.com/archive/2002/March/CT196.shtml.

Blezinger, Stephen B. (2002) Beef Quality Assurance Important for All Operations. Cattle Today. Retrieved 9/2/2002, from http://www.cattletoday.com/archive/2002/April/CT199.shtml.

Cohen, J. (1988). Statistical power analysis for the behavioral sciences $\left(2^{\text {nd }}\right.$ ed.) Hillsdale NJ: Lawrence Erlbaum Associates

Dillman, D. (2000). Mail and internet surveys, the tailored design method. ( $2^{\text {nd }}$ ed.). New York: John Wiley and Sons Inc.

Fowler Jr., F. (1995). Improving survey questions. California: Sage Publications.

Fowler Jr., F. (1988). Survey research methods. California: Sage Publications.

Lavrakas, P. (1993). Telephone survey methods. ( $2^{\text {nd }}$ ed.). California: Sage Publications.

Learn about CSREES. (2003). Retrieved July 31, 2003, from http://ewww.reeusda.gov/1700/about_csrees.htm.

Mid-Atlantic Beef Quality Assurance. (2002) Mid-Atlantic beef quality assurance program certification manual, 2002 Edition. 
National Agricultural Statistics Service (NASS). (1997). Profile of the state's agriculture. Retrieved January 20, 2003 from http://www.nass.usda.gov/census/census97/highlights/wv/wv_fig1.gif.

Newstead, P.R., Huff, S.L., and Munro, M.C. (1998). Survey instruments in information systems. MIS Quarterly, 22, (4), 553-554.

Norland, E. (1992). Why adults participate. Journal of Extension, 30(3). Retrieved January 22, 2003 from http://www.joe.org/joe/1992fall/a2.html.

Ohio Beef Quality Assurance (2001). Ohio beef quality assurance manual.

Osborne, P.I., Pritchard, J. Y., Seymour, D. A., Helmondollar, R., \& Loyd, B.M., (2001). Beef cattle marketing \& feeder cattle marketing. Internal Report to WV Cooperative Extension Service

Taylor, R. (1994). Beef production and management decisions. ( $2^{\text {nd }}$ ed.). New York: Macmillan Publishing Company.

United States Department of Agriculture, Food Safety and Inspection Service. (2002) Focus on: beef... from farm to table. Retrieved January 23, 2003 from http://www.fsis.usda.gov/oa/pubs/focusbeef.htm. 
APPENDICES 
APPENDIX A

Introductory Telephone Statement 
April 4, 2003

Hello, May I speak to (producer's name here) please.

Hello, my name is Sara Peacock. I am conducting a study of the WV Beef Quality Assurance program, I hope that I am not catching you at a bad time. This survey is for my thesis research in partial fulfillment of the requirements for a Master of Science in Agricultural Education in the Davis College of West Virginia University. My Major Professor is Dr. Kerry S. Odell. I got your name from Mr. Jim Bostic of the WV Cattlemen's Association and Dr. Phil Osborne of the WVU Extension Service, as a possible participant to expand knowledge about the producers involved in the program.

Would you mind taking 10 minutes to complete this survey? If this is not a good time, please give me the time that is most convenient for you and I will call back. Participation in this study is voluntary, if at any time you wish to stop the questioning, or leave a question unanswered, you have that option.

My undergraduate degree in Animal and Veterinary Sciences and my current pursuit of a Master of Science in Agricultural and Environmental Education influenced my interest in the Beef Quality Assurance Program. I am attempting to identify the factors that affect participation in the Beef Quality Assurance program. This is a study that should help you, the producer, get the most out of the program in the future. Every effort will be made to keep your information confidential.

The format of this survey is a simple question and answer. I will give you the question and a multiple-choice group of answers and you pick those that best fit your situation. I will be filling in your answers on a form that is in front of me, you will not be taped, and so I may have to ask you to repeat an answer occasionally in order to clarify. After the survey, you will be given a chance to address any issues that you feel have been neglected in the questions. Thank you in advance for your participation in this effort to make the BQA better for you.

Sara D. Peacock 


\section{APPENDIX B}

Telephone Survey 
Beef Quality Assurance Survey

1. How many years have you been farming?

Years

\section{Where is your farm located (region of the state)?}

3. Do you raise any livestock other than cattle? If so what?

\begin{tabular}{|l|l|}
\hline No & \\
\hline Goats & \\
\hline Sheep & \\
\hline Chickens & \\
\hline Pigs & \\
\hline Horses & \\
\hline Dairy Cattle & \\
\hline Other & \\
\hline
\end{tabular}

4. How many head of brood cows do you keep in your herd? head

5. What breed of Cattle do you raise?

\begin{tabular}{|l|l|}
\hline Angus & \\
\hline Hereford & \\
\hline Othessbred & \\
\hline
\end{tabular}

6. What kind of cattle do you concentrate on in your operation?

\begin{tabular}{|l|l|}
\hline Stocker & \\
\hline Cows & \\
\hline Feeder & \\
\hline Cow/ Calf & \\
\hline Other & \\
\hline
\end{tabular}

7. Do you raise any field crops? If so What?

\begin{tabular}{|l|l|}
\hline No & \\
\hline Corn & \\
\hline Hay & \\
\hline Soybeans & \\
\hline Other & \\
\hline
\end{tabular}

8. Is farming your primary source of Income?

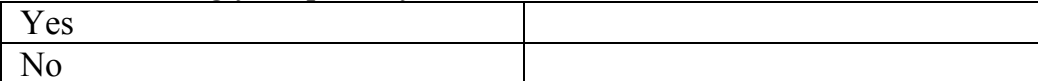

9. What percentage of your income is your farming income?

\begin{tabular}{|l|l|}
\hline Less than $10 \%$ & \\
\hline $10 \%-30 \%$ & \\
\hline $30 \%-50 \%$ & \\
\hline $50 \%-70 \%$ & \\
\hline & \\
\hline
\end{tabular}

10. What was your gross Farm income for 2002 ?

\begin{tabular}{|l|l|}
\hline Less than 5,000 & \\
\hline $5,000-10,000$ & \\
\hline $10,000-20,000$ & \\
\hline $20,000-30,000$ & \\
\hline $30,000+$ & \\
\hline
\end{tabular}

What resources do you use to learn new techniques for your operation?

\begin{tabular}{|l|l|}
\hline Extension Agent & \\
\hline Books & \\
\hline Magazine & \\
\hline Internet & \\
\hline Other & \\
\hline
\end{tabular}


12. Have you read or heard of the Beef Quality Assurance Program? If so, How?

\begin{tabular}{|l|l|}
\hline No & \\
\hline Extension Service & \\
\hline Auction & \\
\hline Cattlemen's Association & \\
\hline Other & \\
\hline
\end{tabular}

13.Are you involved in the BQA Program? If so how long (if yes move on to question 15)

\begin{tabular}{|l|l|}
\hline Yes & \\
\hline No & \\
\hline How Long & \\
\hline
\end{tabular}

14. What do you see as the biggest barrier to your participation in the BQA Program?

\begin{tabular}{|l|l|}
\hline Time & \\
\hline Money & \\
\hline Convenience & \\
\hline Other & \\
\hline
\end{tabular}

15. What would most encourage more participation in the BQA Program?

\begin{tabular}{|l|l|}
\hline Meeting Times & \\
\hline Cool Compliance & \\
\hline Closer meetings & \\
\hline Other & \\
\hline
\end{tabular}

Why are you involved with the BQA Program

\begin{tabular}{|l|l|}
\hline Learn new techniques & \\
\hline $\begin{array}{l}\text { Because extension programs are } \\
\text { recommended }\end{array}$ & \\
\hline It was easy to attend & \\
\hline Other & \\
\hline
\end{tabular}

What are the benefits that you see as a participant in the BQA

Program?

\begin{tabular}{|l|l|}
\hline Social Standing & \\
\hline Beef Prices & \\
\hline Other & \\
\hline
\end{tabular}

16. Have you heard of the trend for Country of Origin Labeling (COOL)?

\begin{tabular}{|l|l|}
\hline Yes & \\
\hline No & \\
\hline
\end{tabular}

19. How much would requirement of this labeling affect the way you do business on your farm?

\begin{tabular}{|l|l|}
\hline Not at all & \\
\hline Very Little & \\
\hline Moderate & \\
\hline Very Much & \\
\hline
\end{tabular}

20. How old were you on your last birthday?

\section{years}

21. What is the highest level of education that you have completed?

\begin{tabular}{|l|l|}
\hline High School & \\
\hline Some College & \\
\hline Bachelor's Degree & \\
\hline Bach + & \\
\hline Other & \\
\hline
\end{tabular}

22. Is there anything else that would affect your participation in the Beef Quality Assurance program that I have not addressed with this survey? 
APPENDIX C

BQA Guidelines from Cattlemen's Association 


\section{Beef Quality Assurance National Guidelines}

\section{Feedstuffs:}

- Maintain records of any pesticide/herbicide use on pasture or crops that could potentially lead to violative residues in grazing cattle or feedlot cattle.

- Adequate quality control program(s) are in place for incoming feedstuffs. Program(s) should be designed to eliminate contamination from molds, mycotoxins or chemicals of incoming feed ingredients. Supplier assurance of feed ingredient quality is recommended.

- Suspect feedstuffs should be analyzed prior to use.

- Ruminant-derived protein sources cannot be fed per FDA regulations.

- Feeding by-products ingredients should be supported with sound science.

\section{Feed Additives and Medications:}

- Only FDA approved medicated feed additives will be used in rations.

- Medicated feed additives will be used in accordance with the FDA Good Manufacturing Practices (GMP) regulation.

- Follow Judicious Antibiotic Use Guidelines.

- Extra-label use of feed additives is illegal and strictly prohibited.

- To avoid violative residues --- withdrawal times must be strictly adhered to.

- Where applicable, complete records must be kept when formulating or feeding medicated feed rations.

- Records are to be kept a minimum of two years.

- Operator will assure that all additives are withdrawn at the proper time to avoid violative residues.

\section{Processing/Treatment and Records:}

- Following all FDA/USDA/EPA guidelines for product(s) utilized.

- All products are to be used per label directions.

- Extra-label drug use shall be kept to a minimum, and uses only when prescribed by a veterinarian working under a Valid Veterinary Client Patient Relationship (VCPR).

- Strict adherence to extended withdrawal periods (as determined by the veterinarian within the context of a valid VCPR) shall be employed.

- Treatment records will be maintained with the following recorded:

1. Individual animal or group identification. 
2. Date treated.

3. Product administrated and manufacture's lot/serial number.

4. Dosage used.

5. Route and location of administration and who administered the product.

6. Earliest date animal will have cleared withdrawal period.

- When cattle are processed as a group, all cattle within the group shall be identified as such, and the following information recorded:

1. Group or lot identification.

2. Date treated.

3. Product administered and manufacturer's lot/serial number.

4. Dosage used.

5. Route and location of administration and who administered the product.

6. Earliest date animal will have cleared withdrawal period.

- All cattle (fed and non-fed) shipped to slaughter will be checked by appropriate personnel to assure that animals that have been treated, meet or exceed label or prescription withdrawal times for all animal health products administrated.

- All processing and treatment records should be transferred with the cattle to next production level. Prospective buyers must be informed of any cattle that have not met withdrawal times.

\section{Injectable Animal Health Products:}

- Products labeled for subcutaneous (SQ) administration should perferrably be administered SQ in the neck region.

- All products labeled for intra-muscular (IM) use shall be given in the neck region only (no exceptions, regardless of age).

- All products cause tissue damage when injected IM. Therefore all IM use should be avoided if possible.

- Products cleared for SQ, IV or oral administration are recommended.

- Products with low dosage rates are recommended and proper spacing should be followed.

- No more than $10 \mathrm{cc}$ of product is administered per IM injection site. 


\section{Care and Husbandry Practices:}

- Follow the 'Quality Assurance Herd Health Plan' that conforms to good veterinary and husbandry practices.

- All cattle will be handled / transported in such a fashion to minimize stress, injury and/or bruising.

- Facilities (fences, corrals, load-outs, etc.) should be inspected regularly to ensure proper care and ease of handling.

- Strive to keep feed and water handling equipment clean.

- Provide appropriate nutritional and feedstuffs management.

- Strive to maintain an environment appropriate to the production setting.

- Bio-security should be evaluated.

- Records should be kept for a minimum of 2 years (3 for Restricted Use Pesticides) 
APPENDIX D

West Virginia BQA Operational Guidelines 


\title{
Operational Guidelines
}

\author{
The West Virginia Beef Quality Assurance Committee
}

\section{Article I}

\section{Section 1. The name of this committee shall be the West Virginia Beef Quality Assurance Committee, a non-profit task force of the West Virginia Cattlemen's Association.}

Section 2. The West Virginia Beef Quality Assurance Committee shall serve as the beef industry representative to the West Virginia Beef Industry regarding beef marketing, quality assurance and safety and shall be responsible for providing advisory management oversight and coordinating designated aspects of the West Virginia Beef Quality Assurance Program (WVBQA).

Section 3. Meeting Place. The principal meeting office shall be in Buckhannon, Upsur County, West Virginia also the location of the West Virginia Cattlemen's Association and The West Virginia Beef Industry Council.

Section 4. The BQA Program shall be administered by the West Virginia Cattlemen's Association in compliance with the Mid - Atlantic BQA guidelines.

\section{Article II \\ Primary Purpose}

Section 1. To strengthen the Beef Quality Assurance initiatives and programs;

Section 2. To draft and update Beef Quality Assurance certification standards and republish as a teaching manual for producers;

Section 3. To conduct a consumer and educational awareness campaign that addresses the salient issues of beef quality and safety.

Section 4. To conduct a consumer educational campaign providing factual information through seminars, the media, schools, and printed materials distributed at consumer tradeshows;

Section 5. To build expansion and stability into other areas of consumer and environmental awareness.

\section{General Purposes and Powers}

Section 1. To receive, administer and monitor the collection of contributions.

Section 2. To administer the program within the state of West Virginia as the qualified West Virginia Beef Quality Assurance Program.

Section 3. To develop contracts and other agreements as may be proper to facilitate the purpose of the program.

Section 4. To appoint and employ such persons as the Committee may deem necessary and to define the duties and to determine the compensation of each employee. 
Section 5. To appoint the sub-committees as the committee may deem necessary. Advisory Committees may be appointed which may include persons who are not members in the WVBQA committee.

Section 6. To provide technical guidance and to implement the BQA program.

Section 7. To develop and schedule training programs for implementers, producers and auditors.

\section{Article III}

\section{Committee Directors}

\section{Section 1. Control. The property, funds and policies of the West Virginia Beef Quality Assurance Program shall be controlled by the WVBQA Committee.}

Section 2. Composition. The WVBQA Committee shall consist of not less than seven (7) nor more than eleven (11) members representing the beef industry in West Virginia.

Such committee membership shall consist of the following:
A. The Executive Secretary of the West Virginia Cattlemen's Association
B. WVU Extension Marketing Specialist
C. WVU Extension Livestock Specialist
D. Livestock Specialist of the WV Dept. of Agriculture Marketing Division
E. WVU Extension Agents
F. One representative from the BQA Marketing Pools
G. One representative from a livestock marketing organization located in West Virginia.
H. At least two WVBQA certified beef producers

Section 3. In order to get broader representation, and to the extent feasible the nominees from WVCA and WVBIC should not be officers or board members of both organizations.

Section 4. Term. The Directors shall serve a three (3 ) year term except for charter members whose terms shall be one-third - two years; one-third - three years and; one-third four years. Beginning July 2003 all terms shall be of three (3) years. No member shall serve more than (2) two consecutive terms. Any member not attending at least $50 \%$ of the meetings shall be asked to resign and a replacement nominated by the sponsoring organization.

Section 5. Meetings shall meet at least quarterly and through liaison with the WVCA. The WVBQA Committee is responsible for preparing the annual authorization request, implement, evaluate and report the WV BQA and Mid-Atlantic BQA programs.

Section 6. Quorum. A majority of the Committee must be present to be considered a quorum for the transaction of business. Each member present shall be entitled to one (1) vote.

Section 7. Compensation. The committee members shall not receive any stated salary for their services. Travel expenses are the responsibility of the representative organization.

Section 8. Annual Report. The BQA Committee is responsible for an annual report immediately preceding the fiscal year; the report shall include financial statements current as of the most recent financial year. 


\section{Article IV}

\section{Officers}

Section 1. Chairperson / Co-Chairman. The Chairpersons shall preside at all meetings of the BQA. The chairpersons shall appoint committees and have the responsibility to submit for approval all budgets, policies and major programs.

Section 2. Secretary-Treasurer. The WVCA Executive Secretary-Treasurer shall call notices for all meetings, shall keep the minutes, have responsibilities of all the monies and securities of the Committee.

Section 5. Removal. Committee members may be removed by affirmative vote of two-thirds of all the committee at any regular or special meeting called for that purpose, for nonfeasance, malfeasance, or misfeasance, for conduct detrimental to the interest of the organization, for lack of sympathy with its objectives, or for the refusal to render reasonable assistance in carrying out its purposes.

\section{Article V}

\section{Directors' Liability}

No committee member of WVBQA shall be personally liable for any action or omission unless the committee member has breached or failed to perform the duties of the office and said breach or failure to perform constitutes self-dealing, willful misconduct or recklessness.

\section{Article VI}

\section{Amendment of Guidelines}

The guidelines may be repealed, modified, altered, and amended at any regular or special meeting of the committee of the WVBQA program. By a two-thirds vote of the committee present, provided that notice of such change shall be given by mail to each member thirty (30) days in advance. 
APPENDIX E

Comments made to Question 22 of the Questionnaire 


\section{Question \# 22. Is there anything else that would affect your participation in the Beef Quality Assurance program that I have not addressed in this survey?}

"Consumer Education is important for credit to be given to the farmers involved in this program, otherwise, they are going the extra mile for little to no recognition of the superior product that BQA helps farmers produce."

"BQA should be required of all cattle that are for sale to outside consumption markets"

"The BQA Program is too much work for the benefits that may be seen"

"If participation in the program was easier, location and such, it would be better."

"A wonderful program that increases the quality of our cattle."

"Doesn't feel that the they need it the way the market situation is today, but if the information gets out there, thinks that it could be a good thing."

"We need Consumer Education!!!"

"There should be government incentives to assist with the program or to reward those who participate, like tax breaks or something."

“ Marketing with BQA could be very helpful if the buyers understood the value of the program"

"Accessibility to the program is there if the producer is motivated enough to want it"

"It seems like a good program, but not practical for this operation"

"West Virginia market is tough to be involved in, needs some help."

"This is what I see that could improve the BQA program. 1. Cost of Vaccines, 2. Quality of feeds, a tested diet would be good, and a sale with only cattle, no names since many business transactions are built on a name rather than the product, would give the newer producers a chance to see how their cattle measure up."

"COOL will help the industry."

"it is a risk because if the market drops, BQA producers will not get their premiums for their cattle"

"It is the future of the cattle industry, once the consumer knows that some cattle are better than others at the farm level and that this can follow them through to market, producers will be rewarded for their perseverance to technologically better herd care." 
"Certain markets do not benefit from BQA procedures, some growers have contracts with packers who want animals with no hormones or antibiotics, BQA does not have a program for herd health for these types of producers."

"Nutrient management, such as Water quality relating to farm runoff, needs to be addressed."

"If you can prove to the farmers that BQA will make them more money, they will participate in it."

"If we can get awareness out there to the producers and to the consumers, then the middlemen will have to keep up with the demand and the market for BQA cattle will improve."

"Permanent ID system, money behind the program, it will go further, need to address the independence of farmers"

"Get the premium prices for the effort of BQA, then more will participate."

"Some farmers feel that there is too much intervention by the government on the type of product that they produce, they need to be reminded of the assistance that they expect from the government for their operation... water, NRCS STUFF, etc"

"Program awareness is key."

"People need to understand how the BQA program can affect their herd and the industry, then it will be easier to get participation."

"Those who know it, use it. It is tough to reach the "backyard farmers who just grow 10 or so, need to figure out how to address them, improve the market from the ground up."

"Innovative marketing could really kick start this throughout the country."

"Carcass data could be a point of proof, many serious producers would do something to get that kind of data back."

"I don't want them telling me what I have to raise and do to the cattle on my farm"

"Takes the wait out of graded sale weigh in time."

"Send out a newsletter in the winter, that's when we have time to read it."

"It's a pretty good program"

"Before I joined the BQA program I had to hire help to get my cattle worked, since we work together, I don't have to do that now, I like that." 
APPENDIX F

Geographic Location of Respondents 
Geographic Location of Respondents

\begin{tabular}{|c|c|c|c|c|c|c|}
\hline \multirow[b]{2}{*}{ Characteristic } & \multicolumn{2}{|c|}{$\begin{array}{c}\text { Non Member } \\
\text { BQA }\end{array}$} & \multicolumn{2}{|c|}{$\begin{array}{c}\text { Member } \\
\text { BQA }\end{array}$} & \multicolumn{2}{|c|}{ Overall } \\
\hline & \# & $\%$ & \# & $\%$ & \# & $\%$ \\
\hline \multicolumn{7}{|l|}{ County } \\
\hline Barbour & 1 & 1.9 & 2 & 6.3 & 3 & 3.5 \\
\hline Berkeley & 3 & 5.7 & 0 & 0.0 & 3 & 3.5 \\
\hline Braxton & 0 & 0.0 & 2 & 6.3 & 2 & 2.4 \\
\hline Clay & 0 & 0.0 & 1 & 3.1 & 1 & 1.2 \\
\hline Doddridge & 1 & 1.9 & 0 & 0.0 & 1 & 1.2 \\
\hline Gilmer & 1 & 1.9 & 0 & 0.0 & 1 & 1.2 \\
\hline Grant & 4 & 7.5 & 1 & 3.1 & 5 & 5.9 \\
\hline Greenbrier & 2 & 3.8 & 0 & 0.0 & 2 & 2.4 \\
\hline Hampshire & 5 & 9.4 & 0 & 0.0 & 5 & 5.9 \\
\hline Hardy & 2 & 3.8 & 5 & 15.6 & 7 & 8.2 \\
\hline Harrison & 3 & 5.7 & 1 & 3.1 & 4 & 4.7 \\
\hline Jefferson & 1 & 1.9 & 1 & 3.1 & 2 & 2.4 \\
\hline Lewis & 2 & 3.8 & 0 & 0.0 & 2 & 2.4 \\
\hline Marion & 1 & 1.9 & 0 & 0.0 & 1 & 1.2 \\
\hline Mineral & 3 & 5.7 & 0 & 0.0 & 3 & 3.5 \\
\hline Monongalia & 0 & 0.0 & 4 & 12.5 & 4 & 4.7 \\
\hline Monroe & 0 & 0.0 & 1 & 3.1 & 1 & 1.2 \\
\hline Pendleton & 3 & 5.7 & 1 & 3.1 & 4 & 4.7 \\
\hline Pleasants & 1 & 1.9 & 0 & 0.0 & 1 & 1.2 \\
\hline Pocahontas & 1 & 1.9 & 0 & 0.0 & 1 & 1.2 \\
\hline Preston & 6 & 11.3 & 0 & 0.0 & 6 & 7.1 \\
\hline Randolph & 1 & 1.9 & 3 & 9.4 & 4 & 4.7 \\
\hline Roane & 4 & 7.5 & 2 & 6.3 & 6 & 7.1 \\
\hline Taylor & 3 & 5.7 & 1 & 3.1 & 4 & 4.7 \\
\hline Tucker & 0 & 0.0 & 3 & 9.4 & 3 & 3.5 \\
\hline Tyler & 1 & 1.9 & 0 & 0.0 & 1 & 1.2 \\
\hline Upshur & 4 & 7.5 & 3 & 9.4 & 7 & 8.2 \\
\hline Wood & 0 & 0.0 & 1 & 3.1 & 1 & 1.2 \\
\hline
\end{tabular}

*Counties with no participants in the survey are not listed in this table 


\section{VITA}

Education:

Professional Experience:
May 2000

August 2003

June 2000-August 2002

Fall 1998-Spring 2000
Bachelor of Science

Animal and Veterinary Sciences

West Virginia University

Morgantown, West Virginia

Master of Science

Agricultural and Environmental Education

West Virginia University

Graduate Assistant

to Associate Dean for Academic Affairs

Davis College

West Virginia University

Morgantown, West Virginia

Student Assistant at Food Animal Research

Facility, for Davis College

West Virginia University

Morgantown, West Virginia 